\title{
Analysis of base sector, coefficient of localization and specialization to detect the superiorcommodity of livestock in Regency of South Bolaang Mongondow Provinceof North Sulawesi, Indonesia
}

\author{
Erwin Wantasen*1), Sintya Umboh ${ }^{1)}$, and Eusebius Endoh ${ }^{1)}$ \\ ${ }^{1)}$ Department of Socio-Economic, Faculty of Animal Husbandry, Sam Ratulangi University \\ Jalan Kampus Manado, 95115, Indonesia
}

Submitted: 14 May 2019, Accepted: 24 January 2020

\begin{abstract}
This study aimed to know the type of the superior commodity of livestock and the structure of livestock growth in Regency of South Bolaang Mongondow, Province of North Sulawesi. This research was performed in three districts, such as District of Bolang Uki, District of Posigadan, and District of Pinolosian, possessing the largest ruminant and non-ruminant livestock population. Ninety respondents of breeders were randomly selected, consisting of cattle, goat, native chicken, broiler, egg-layer, and duck breeder, respectively 15 respondents. Data collected was then analyzed using analysis of location quotient (LQ), coefficient of localization and specialization. According to the result of location quotient (LQ) analysis, cattle, goat, native chicken, and the duck was the superior commodity, becoming a base sector in Regency of South Bolaang Mongondow obtaining value of LQ >1. From four of the superior commodities, nonetheless, only did cattle have more than one coefficient value of localization (1.020), depicting that cattle had been localized in the study area to sustain the local economy. The analysis of specialization showed that Regency of South Bolaang Mongondow had not self-specialized for certain types of livestock to develop regional economy, presented by the coefficient value of specialization which was still lower than one.
\end{abstract}

Keywords: the superior commodity; base sector; localization; specialization

\footnotetext{
*Corresponding Author: erwinwantasen@yahoo.co.id
} 


\section{INTRODUCTION}

An integrated development of the leading commodity in the agribusiness system, starting from upstream toward downstream, will contribute to the regional economy, improvement of the public's income and job opportunity (Masniadi dan Sasongko, 2012). The superior commodity in any regional economy determines the regional economy in total. The greater the income flow in a certain area, the faster the activity of other sectors, and, as consequence, it will give a positive effect simultaneously toward the regional economy (Kristiawan et al., 2016). One of the sectors possessing potential contribution in boosting up the regional economy is animal husbandry. An effort that can be done in improving contribution of sub-sector of animal farming against gross regional-domestic products (PDRB) and, in the same time, as driving sector of regional economy growth is by developing the first-class or superior commodity, business efficiency, and competitiveness of livestock commodities (Suyitman et. al. 2009; Soedjana and Priyanti, 2017; Elsedig, Mohd and Fatimah, 2015; Oluwatayo and Senyolo, 2016; Khasanah, 2018)

Especially, Regency of South Bolaang Mongondow is an area having abundant and rich natural resources, mainly on the sub-sector of livestock. Unfortunately, there have no efforts, however, to manage this sub-sector maximally. Whereas, the sub-sector of animal husbandry has the biggest development of other sub-sectors of agriculture, $6,93 \%$ higher than the development of sub-sector of fishery of $6,03 \%$, where this area is a southerly coastal of Province of North Sulawesi directly bordered with Moluccas Sea, having rich of marine harvest. On contrarily, the contribution of Regency of South Bolaang Mongondow against the regional economy of North Sulawesi Province relatively short $(1,57 \%)$. This is due to the Local Government of Regency
ofSouth Bolaang Mongondow has not maximally developed the commodity of agriculture, including livestock. They have not obtained correct and precise information to identify the type of commodities, becoming local superiority and having high potential commodity to be developed further. According to data of Biro Pusat Statistik Kabupaten Bolaang Mongondow Selatan (2018), a total of cattle was 5,541 cattle, goat was 4,582 goats, pig was 681 pigs, domestic chicken was 58,839 chickens, broiler was 3,000 broilers, egg-layer was 2,000 egg-layers and duck was 5,833 ducks. Several studies have reported the role of leading agriculture commodity in the economics of region but information of the structure of livestock commodity growth is still limited (Alhowaish et al., 2015; Hendayana, 2003; Herrero et al., 2012)

Therefore this research is aimed to investigate livestock commodity becoming the first-class or base sector from Regency of South Bolaang Mongondow and structure of livestock commodity growth, so that it can be reliable and beneficial source of information for the Local Government in managing livestock sector to be the superior sector in improving its societal economy and can provide better contribution toward regional economy of Province of North Sulawesi.

\section{MATERIALS AND METHODS \\ Site, Sampling Technique, and Data Collecting}

The research was performed in three districts, such as District of Bolang Uki, District of Posigadan, and District of Pinolosian having the largest ruminant and non-ruminant livestock population (BPS Bolaang Mongondow Selatan, 2018). In each district, then, one village was chosen respectively, such as Village of Salongo (Regency of Bolang Uki), Village of Milangodaa Barat (District of Posigadan) and Village of Pinolosian (District of Pinolosian) by their potency and total of 
livestock possessed. Ninety samples of breeder were selected as respondent, comprising of 15 respondents of cattle breeder, 15 respondents of native chicken breeder and 15 respondents of duck breeder in Village of Pinolosian; 15 respondents of goat breeder in Village of Milangodaa Barat; and 15 respondents of broiler and egg-layer poultryman, respectively, in Village of Salongo. Both primary and secondary data were collected by survey technique from October up to November 2018. Primary data consisted of age, education, a total of a household member, cultivated area, experience in raising livestock, cost, revenue and income of animal farming.

While, secondary data comprised of total of area according to land utilization, climatology data, gross regional-domestic products (PDRB), regional economy growth, production value of each

$$
\text { Location Quotient }\left(\mathrm{LQ}_{\mathrm{i}}\right)=\frac{p_{i k / P i p}}{K / P}
$$

commodity of livestock in the level of regency and province, and production value of total of livestock commodities in the level of regency and province, which each variable of secondary data collected within the last $5 \mathrm{y}$ of 2014-2018obtained from Governmental institutions, such as Board of Development and Research Planning (Bappelitbang)Regency of South Bolaang Mongondow, Central Statistic Bureau of North Sulawesi Province, Service of Agriculture, Foods, livestock, and Fishery of Regency ofSouth Bolaang Mongondow.

\section{Data Analysis}

Various data collected, hence, were analyzed using the following formulation as hereunder Alhowaish et al., 2015). To know whether livestock commodity is the first-class or base commodity in Regency of South Bolaang Mongondow or not, analysis of Location Quotient (LQ) was utilized.

Where:

$\mathrm{P}_{\mathrm{ik}} \quad=$ Production value of each livestock commodity $i$ in the level of regency

$\mathrm{P}_{\mathrm{ip}} \quad=$ Production value of each livestock commodity $i$ in the level of province

$\mathrm{K}=$ Total of production value on all livestock commodities in the level of regency

$\mathrm{P}=$ Total of production value on all livestock commodities in the level of province

Criteria of decision-making process was as hereunder:

Whereas LQi >1: Livestock commodity $i$ was the leading commodity and became basic economy sector

Whereas LQ $\leq 1$ : Livestock commodity $i$ was not the leading commodity and became nonbasic economy sector

To acknowledge structure of livestock commodity growth in Regency of South Bolaang Mongondow, analysis of localization and specialization was performed (Glasson, 1997)

Coefficient of Localization $(\alpha \mathrm{i})=\mathrm{Pik} / \mathrm{Pip}-\mathrm{K} / \mathrm{P}$
Coefficient of Specialization $(\beta \mathrm{i})=(\mathrm{Pik} / \mathrm{K}-\mathrm{Pip} / \mathrm{P})$

Criteria of decision-making process was as hereunder:

Whereas $\alpha \mathrm{i} \geq 1$ : Livestock commodity $i$ was localized in certain area

Whereas $\alpha \mathrm{i}<1$ : Livestock commodity $i$ was spread in several areas

Whereas $\beta \mathrm{i} \geq 1$ : Livestock commodity $i$ was specialized in certain area

Whereas $\beta \mathrm{i}<1$ : Livestock commodity $i$ was not specialized in certain area

To know income and cost of production from animal farming activity conducted by breeders, analysis of income was used (Umar, Alamu and Adeniji, 2008) 
$\mathrm{P}=\mathrm{TR}-\mathrm{TC}$

Where:

$\mathrm{P}=$ Income of breeder in each of livestock commodities (IDR/Year)

$\mathrm{TR}=$ Total of receiving from breeder in each of livestock commodity (IDR/Year)

$\mathrm{TC}=$ Total of cost from each livestock commodity (IDR/Year)

\section{RESULTS AND DISCUSSION Characteristic of respondents}

All animal farming activities in the research area typically are still part-time activity, based on time allocation given by breeder averagely $1-4 \mathrm{~h}$ per $\mathrm{d}$ and varied according to the type of livestock. Respondent of breeders had the biggest time in raising cattle of 3.5 to $4.5 \mathrm{~h}$ per $\mathrm{d}$, and they had the smallest time allocation to cultivate native chicken for about $1 \mathrm{~h}$ per $\mathrm{d}$. This characteristic of the respondent of breeders located in three districts can be seen in the following Table 1. Reveals that age of respondent of breeders was mostly in productive age where 43-57 percent of breeders were aged between 41-50 y old, they had formal education averagely Senior High School and University, cultivated area was relatively small, and they had better experience in cultivating livestock, which was more than $5 \mathrm{y}$. Additionally, those breeders did not only obtain a formal education, but also informal education through counseling of technical procedures of husbandry conducted by counselor of agriculture of Regency of Bolaang Mlongondow Selatan.

Table 1. Characteristic of respondent of breeders in regency of South Bolaang Mongondow

\begin{tabular}{cccc}
\hline Characteristic of respondents & \multicolumn{3}{c}{ Districts (\%) } \\
\cline { 2 - 4 } & Bolang Uki & Posigadan & Pinolosian \\
\hline Age (Y): & 16.7 & 0.0 & 8.6 \\
$21-30$ & 33.3 & 14.0 & 24.3 \\
$31-40$ & 43.3 & 33.0 & 57.2 \\
$41-50$ & 6.7 & 53.0 & 9.9 \\
$\geq$ 50 & & & \\
Education : & 27.5 & 22.1 & 17.4 \\
Elementary & 53.4 & 47.6 & 32.6 \\
Junior High School & 19.1 & 24.3 & 45.3 \\
Senior High School & 0.0 & 6.03 & 4.7 \\
University & & & 36.0 \\
Family Member (People): & 33.0 & 30.0 & 52.0 \\
1-2 & 43.0 & 48.0 & 14.0 \\
$3-4$ & 24.0 & 12.0 & \\
$5-6$ & & & 81.0 \\
Area (Ha): & 70.0 & 76.0 & 19.0 \\
$0.1-1.49$ & 30.0 & 24.0 & \\
1.5 - 2.4 & & & 9.0 \\
Experience (Y): & 57.0 & 18.0 & 47.0 \\
$5-10$ & 32.0 & 37.0 & 39.0 \\
$11-20$ & 11.0 & 40.0 & 5.0 \\
$21-30$ & 0.0 & 5.0 & \\
$\geq 31$ & & & \\
\hline
\end{tabular}

Source: Data processed 


\section{Cost, Revenue and Income of animal farming}

Income of animal farming is a difference in all revenue by selling products and the cost of production expensed during cultivating livestock. In animal farming, the cost of production comprises of cost of feed, cages, medicines, cost of labor, land area, purchasing of livestock's seeds, or kernels, insemination and warehouse of feed storing, cage's depreciation and cage's equipment, livestock's depreciation. In addition, revenue is the result of products sold comprising of lively livestock, meat, eggs, rejected chickens, softly cracked eggs, labor of cattle and waste products such as feces,waste of husk,compact fertilizer, liquid fertilizer, and biogas (Moharrery, 2007;Umar, Alamu and Adeniji, 2008; Dinka et al., 2010; Kemi, 2016).

However, based on the result of research, the livestock products sold were only lively livestock, meat, eggs, rejected chickens, softly cracked eggs, labor of cattle, waste of husk and compost, but other side products, namely solidly and liquidly organic fertilizer and biogas, had not become source of income for breeders in South Bolaang Mongondow regency. Averagely, the rate of the cost of production, receiving and income of breeders in each livestock commodity cultivated is shown in Table 2.

Table 2. Rates of Cost of Animal Production in Regency of South Bolaang Mongondow

\begin{tabular}{lccc}
\hline \multirow{2}{*}{$\begin{array}{c}\text { Type of } \\
\text { Commodity }\end{array}$} & \multicolumn{2}{c}{ Type of Cost } & Total of Cost \\
\cline { 2 - 3 } & Fixed Cost (IDR/Year) & Variable Cost (IDR/Year) & (IDR/Year) \\
\hline Cattle & 177.625 & 13.138 .520 & 13.316 .145 \\
Goat & 368.850 & 1.749 .100 & 2.117 .950 \\
Domestic Chicken & 545.280 & 2.387 .166 & 2.932 .446 \\
Broiler & 11.086 .335 & 92.180 .000 & 103.266 .335 \\
Egg-layer & 27.565 .278 & 86.663 .730 & 114.229 .008 \\
Duck & 183.150 & 37.980 .000 & 38.163 .150 \\
\hline
\end{tabular}

Source: Data processed

As shown in Table 2 that the largest cost of animal production was derived from broiler and egg-layer production. It has happened since breeders had to expense mostly cost of feed-in great number for securing their livestock production. Contrastingly, breeders of domestic chicken and goat expensed a relatively small number of costs of production since both livestock was cultivated extensively so that it could reduce the cost of feed being the biggest cost component in animal farming. In the same vein, this finding was in line with the works of Alfa, Ekowanti, and Handayani (2016) and Maulana, Prasetyo, and Sarenggat (2017).

Another study by Hartono and Rohaeni (2014) reporting that the percentage of the cost of production conducted in broiler, egg-layer, and cattle in Regency of Batang, Regency of
Kuninganand Regency of Tanah Laut was dominated by the cost of feed, reaching out 76-82 percent.

Further, Table 3 below depicts that income from respondents of breeder derived from a variety of animals they run of is as follows, According to the result of research in Table 3, it is known that broiler and egg-layer had the biggest averagely annual income than others, respectively IDR 18.938.763/year and IDR 24.993.992/year. While, other commodities of livestock comprising of domestic chicken, goat, cattle, and duck, had an average income of IDR 1.672.220 up to IDR 7.305.600 per year. Nonetheless, overall, all livestock located in Regency of South Bolaang Mongondow provided a beneficial incentive for breeders. The amount of income derived from broiler and egg-layer was resulted from management 
of cultivating performed by breeders having followed technical standard of animal cultivating so that it was in line with experience obtained from agricultural extension, such as total and mechanism of feeding, cage management, higher demand from society against both types of livestock surrounding study area, and price of broiler and egg-layer was relatively cheaper than price of cattle or goat and price of meat of domestic chicken Moreover, the demand for cattle and goat was only occurred during Moslem's religious days-Eid alAdha and Eid Fitri- or other religious days with relatively expensive price. Also, the business scale of cattle and goats in this research site was relatively low, consisting of 1-2 cattle dan 2-4 goats. Similarly, this finding was corresponding to Maulana, Prasetyo, and Sarenggat (2017) showing that egg-layer in the District of Tersono had been performed by good management through better production and marketing management. Semi-intensive goat farming obtained income of IDR 3,274,856 per year (Manurung, Hasnudi, and Supriana, 2018) and goat farming extensively cultivated in Regency of South Bolaang Mongondow provided averagely annual income was IDR $2,516,827$.

Table 3. Rates of Income from Each Breeder in Regency of South Bolaang Mongondow

\begin{tabular}{lccc}
\hline \multicolumn{1}{c}{$\begin{array}{c}\text { Type of } \\
\text { Commodity }\end{array}$} & $\begin{array}{c}\text { Revenue of } \\
\text { farming(IDR/Year) }\end{array}$ & $\begin{array}{c}\text { Cost of Production } \\
\text { (IDR/Year) }\end{array}$ & $\begin{array}{c}\text { Income } \\
\text { (IDR/Year) }\end{array}$ \\
\hline Cattle & 16.348 .333 & 13.316 .145 & $3,032,188$ \\
Goat & 4.634 .777 & 2.177 .950 & 2.516 .827 \\
Domestic Chicken & 4.604 .666 & 2.932 .446 & 1.672 .220 \\
Broiler & 122.205 .098 & 103.266 .335 & 18.938 .763 \\
Egg-layer & 139.223 .000 & 114.229 .008 & 24.993 .992 \\
Duck & $45.468,750$ & 38.163 .150 & 7.305 .600 \\
\hline
\end{tabular}

Source: Data Processed

\section{Analysis of Location Quotient (LQ)}

The first-class product is any product enabling to provide income contribution for certain region using well-known criteria and widely developed by society, having significant contribution against local economy and having competitiveness with other commodities, and having market's potency and orientation, either domestic or export (Pongi et al., 2015). The result of location quotient (LQ) analysis from livestock commodity located in Regency of Bolaang Mongondow Selatan is served in the following Table 4.

In Table 4, the finding shows that, during 2016-2018, cattle, goat, broiler, and duck were the superior livestock or base sector in the study area since the value of LQ was larger than one (LQ>1). It means that areas in Regency of South Bolaang Mongondow were able to supply their demand of four types of such commodities and able to export or supply other areas concerning on-demand of cattle, goat, broiler, and duck. Whereas, on the other side, domestic chicken and egg-layer were not the leading commodities in the study area since the value of LQ was smaller than $(\mathrm{LQ}<1)$.

It means that areas in Regency of South Bolaang Mongondow had not been able to supply their demand for domestic chicken and egg-layer, but it had to be imported from other areas. This finding was in the same tone with the work of Hendayana (2003) stating that one of the indicators from the first-class commodity was a wide regional distribution, and, in contrast, any commodity classified as nonsuperior commodity had only narrow regional distribution or it had not been able to be exported in other regions. 
Table 4. Location Quotient (LQ) Analysis of Livestock Commodity in Regency of South Bolaang Mongondow

\begin{tabular}{lcccc}
\hline \multirow{2}{*}{ Type of Livestock } & \multicolumn{3}{c}{ Year } & \multirow{2}{*}{ Average } \\
\cline { 2 - 4 } \cline { 2 - 3 } Cattle & 2016 & 2017 & 2018 & 1.693 \\
Goat & 1.784 & 1.637 & 1.660 & 1.374 \\
Domestic Chicken & 1.295 & 1.440 & 1.389 & 0.669 \\
Broiler & 0.342 & 0.773 & 0.893 & 1.598 \\
Egg-layer & 1.557 & 1.864 & 1.375 & 0.603 \\
Duck & 0.635 & 0.449 & 0.726 & 1.391 \\
\hline
\end{tabular}

Source: Data Processed

\section{Coefficient of Livestock Localization Analysis}

Analysis of livestock is performed by using the coefficient of localization of which this coefficient value describes whether or not the commodity of livestock is distributed or localized in a certain area (Herrero et al., 2012). Thus, the finding of this research shown in the following Table 5 reveals the coefficient of localization from each commodity of livestock in Regency of South Bolaang Mongondow.

Table 5. Analysis $(\alpha)$ of Livestock Commodity in Regency of South Bolaang Mongondow

\begin{tabular}{lcccc}
\hline \multicolumn{1}{c}{ Type of Livestock } & \multicolumn{3}{c}{ Year } & \multirow{2}{*}{ Average } \\
\cline { 1 - 4 } Cattle & 2016 & 2017 & 2018 & \\
Goat & 0.896 & 1.077 & 1.089 & 1.020 \\
Domestic Chicken & 0.665 & 0.704 & 1.104 & 0.824 \\
Broiler & 0.218 & 0.553 & 0.687 & 0.486 \\
Egg-layer & 0.795 & 0,587 & 0.664 & 0.682 \\
Duck & -0.039 & 0.102 & -0.026 & -0.012 \\
\hline
\end{tabular}

Source: Data Processed

Based on table 5, the finding demonstrates that, among all livestock commodities in Regency of South Bolaang Mongondow, cattle were the only livestock concentrated in Regency of Bolaang Mongondow Selatan, which its coefficient value of localization $(\alpha)$ was more than one, and other livestock such as goat, domestic chicken, broiler, egg-layer, and duck was not localized in area of Bolaang Mongondow Selatan, which its coefficient value of localization $(\alpha)$ was smaller than one. The cattle mostly localized in Regency of Bolaang Mongondow Selatan was due to most of the residents in this area had turned cattle as their household's source of income, so that areas in Regency of South Bolaang Mongondow became source of cattle production in Province of North Sulawesi. On the other hand, even though goat, broiler, and duck was the superior commodity but such livestock had not concentrated in the research site and still distributed in other areas of Province of North Sulawesi. Such a condition indicated that the first-class commodity of a certain area was not always concentrated in such an area. This finding was in line with the study of Kasuba, Panelewen, and Wantasen (2015) stating that even though the commodity of chili and durian became base or the leading sector in Regency of Halmahera Selatan, it was likely not concentrated in such area specifically.

\section{Analysis of Specialization}

Analysis of specialization was intentionally aimed to know whether or not Regency of Bolaang Mongondow Selatan self-specialized for certain commodities of livestock. To acknowledge the extent of 
specialization in a certain area based on the type of certain commodity, analysis of specialization coefficient $(\beta)$ was performed. The finding of the research then was related to the coefficient of specialization from various types of livestock in study sites served in the following Table 6 . Table 6 displays that, similar to the coefficient of localization, all types of livestock, including the leading commodity existing in Regency of South Bolaang Mongondow comprising of cattle, goat, broiler, and duck, had not been specialized in this area. It means that Regency of South Bolaang Mongondow had not self-specialized its first-class commodity of livestock in the development of the regional economy.

Table 6. Analysis of Specialization from Livestock Commodity in Regency of South Bolaang Mongondow

\begin{tabular}{lcccc}
\hline \multirow{2}{*}{ Type of Livestock } & \multicolumn{3}{c}{ Year } & \multirow{2}{*}{ Average } \\
\cline { 2 - 4 } & 2016 & 2017 & 2018 & 0.956 \\
Cattle & 0.726 & 1.063 & 1.081 & 0.645 \\
Goat & 0.545 & 0.386 & 1.005 & 0.356 \\
Domestic chicken & 0.131 & 0.358 & 0.579 & 0.213 \\
Broiler & 0.195 & 0.226 & 0.218 & -0.013 \\
Egg-layer & -0.085 & 0.125 & -0.077 & -0.240 \\
Duck & -0.341 & -0.139 & 0.052 &
\end{tabular}

Source: Data Processed

It was due to animal production had not utilized recommended technology, such as intensive cultivation, utilizing the qualified type of feed, usage of reproduction technology for cattle and goat and a relatively small scale of broiler and duck. The improvement of regional economy sourced in livestock commodities can be done if the utilization of reproduction and production technology and the best quality of feed is wellperformed consistently (Herrero et al., 2012; Alarcon et al., 2017).

\section{CONCLUSION}

Livestock of cattle, goat, broiler, and duck is the base sector or the superior commodity from Regency of South Bolaang Mongondow that can be turned as a commodity in developing the regional economy. Cattle is the first-class livestock having been localized, but, in contrast, having not been specialized in Regency of South Bolaang Mongondow. Also, goat, broiler, and the duck is the leading commodity of livestock that has not been either localized or specialized commodity in the study site. The livestock of domestic chicken and egg-layer has not been the superior commodity in the Regency of South Bolaang Molngondowsince it has not been either localized or specialized. Therefore the local government of South Bolaang Mongondow Regency should optimize the utilization of cattle, goat, broiler, and duck as a superior commodity by better production management to increase the contribution of this livestock on the regional economy.

\section{ACKNOWLEDGMENT}

First of all many thanks to DRPM Ristek Dikti for funding us by the research scheme of Institutional strategic national research (PSNI) in 2018 and second turn for my team for their cooperation so that we can accomplish the activity of this research.

\section{REFERENCES}

Alarcon, P., Dominguez-Salas, P., Häsler, B., Rushton, J., Alarcon, P., Fèvre, E. M., Ahmed, S. (2017). Mapping of beef, sheep and goat food systems in Nairobi - A framework for policy making and the identification of 
structural vulnerabilities and deficiencies. Agricultural Systems, 152, 1-17. https://doi.org/10.1016/ j.agsy.2016.12.005

Alfa, H., Ekowati, T., \& Handayani, M. (2016). Analisis pendapatan usaha ayam broiler di Kecamatan Jalaksana Kabupaten Kuningan Jawa Barat. MEDIAGRO, 12(2), 65-73.

Alhowaish, A., Alsharikh, M., Alasmailand, Z., \& Alghamdi. (2015). Location quotient technique and economy analysis of regions: Tabuk Province of Saudi Arabia as a case study. International Journal of Science and Research (IJSR), 4(12), 1756-1761. https://doi.org/10.21275/ v4i12.nov152375

Biro Pusat Statistik Kabupaten Bolaang Mongondow Selatan. (2018). Bolaang Mongondow Selatan Dalam Angka.

Dinka, H., Chala, R., Dawo, F., Leta, S., \& Bekana, E. (2010). Socio-economic importance and management of village chicken production in rift valley of Oromia, Ethiopia. Livestock Research for Rural Development, 22(11), article \#203.

Elsedig, E. A. A., Mohd, M. I., \& Fatimah, M. A. (2015). Assessing the competitiveness and comparative advantage of broiler production in Johor using policy analysis matrix. International Food Research Journal, 22(1), 116-121.

Glasson, J. (1997). Pengantar Perencanaan Wilayah (3rd ed.). Jakarta: UI Press.

Hartono, B., \& Rohaeni, E. S. (2014). Contribution to income of traditional beef cattle farmer households in Tanah Laut Regency, South Kalimantan, Indonesia. Livestock Research for Rural Development, 26(8).

Hendayana, R. (2003). Aplikasi metode location quotient (LQ) dalam penentuan komoditas unggulan nasional. Jurnal Informatika Pertanian, 12, 1-21.

Herrero, M., Grace, D., Njuki, J., Johnson, N., Enahoro, D., Silvestri, S., \&
Rufino, M. C. (2013). The roles of livestock in developing countries. Animal, 7(SUPPL.1), 3-18. https:// doi.org/10.1017/S1751731112001954 Kasuba, S., Panelewen, V. V., \& Wantasen, E. (2015). Potensi komoditi unggulan agribisnis hortikultura dan strategi pengembangannya di Kabupaten Halmahera Selatan. ZOOTEC, 36(1), 390-402. https://doi.org/10.35792/zot 35.2.2015.9988

Kemi, A. (2016). Economic impact of livestock production on the society: A case study of Ikare Akoko Ondo State. Journal of Agriculture and Veterinary Science, 9(12), 77-80.

Khasanah, N. (2018). Komoditas tanaman pangan dan ternak unggulan di Kabupaten Banyumas. Jurnal Pertanian Agros, 20(2), 74-78.

Kristiawan, K., AR, N. H., Soemarno, S., \& Tyasmoro, S. Y. (2016). Leading product development of fruits using location quotient in Tuban regency. IOSR Journal of Agriculture and Veterinary Science, 9(8), 81-84. https:// doi.org/10.9790/2380-0908018184

Manurung, J., Hasnudi, \& Supriana, T. (2018). Income Analysis Of Goatfarmers In The Farmers Groupin District of Serdang Begadai. In International Conference on Agriculture, Environment and Food Security. Proceeding of IOP Conf. Series. Earth and Environmental Science 122(012133). IOP Publishing.

Masniadi, R., \& Sasongko, A. (2013). Analisis komoditas unggulan pertanian untuk pengembangan ekonomi daerah tertinggal di Kabupaten Sumbawa Barat. Jurnal Ekonomika Bisnis, 3(1), 51-64. https:// doi.org/10.22219/jekobisnis.v3i1.2228

Maulana, F. H., Prasetyo, E., \& Sarengat, W. (2018). Analisis pendapatan usaha peternakan ayam petelur sumur banger farm Kecamatan Tersono Kabupaten Batang. MEDIAGRO, 13(2), 51-64. https://doi.org/10.3194 2/MD.V13I2.2155 
Moharrery, A. (2007). The determination of buffering capacity of some ruminant's feedstuffs and their cumulative effects on TMR ration. American Journal of Animal and Veterinary Sciences, 2(4), 72-78. https: //doi.org/10.3844/ajavsp.2007.72.78

Oluwatayo, I., \& Senyolo, M. (2016). Profitability and efficiency analysis of smallholders broiler production in Mopani district of Limpopo Province South Africa. Journal of Agribusiness and Rural Development, 1(39), 145-154.

Pongi, S., Antara, M., Mahfudz, \& Rustam. (2015). Superior commodities potensialand the strategy development in Sigi District Senttral Sulawesi Province. IOSR Journal of Agriculture and Veterinary Science, 4(11), 23-30.
Soedjana, T. D., \& Priyanti, A. (2017). Competitiveness of Indonesian Livestock Production among ASEAN Countries. Indonesian Bulletin of Animal and Veterinary Sciences, 1(39), 145-154. https://doi.org/10.14 334/wartazoa.v27i1.1411

Suyitman, Surjono, H., Herison, C., \& Muladno. (2009). Status keberlanjutan wilayah berbasis peternakan di Kabupaten Situbondo untuk pengembangan kawasan agropolitan. Jurnal Agro Ekonomi, 22(2), 165-191. https://doi.org/10.25 015/penyuluhan.v13i1.14641

Umar, A. S., Alamu, J., \& Adeniji, O. (2008). Economic analysis of small scale cow fattening enterprise in Bama Local Government area of Borno State Nigeria. Production Agriculture and Technology Journal, 4(1), 1-10. 